\title{
Komputasi Simbolik dengan REDUCE untuk menentukan validasi Silogisme dan aplikasinya dalam Fisika
}

\author{
Arief Hermanto
}

\begin{abstract}
Ringkasan
Silogisme adalah sebuah bentuk argumentasi dalam logika. Penelitian ini bertujuan untuk menghasilkan program komputer dalam komputasi simbolik untuk menentukan validasi silogisme dan kemudian diaplikasikan dalam Fisika. Bahasa yang dipilih adalah REDUCE berdasarkan berbagai pertimbangan, salah satu di antaranya adalah karena REDUCE adalah bahasa yang open source. Pertimbangan lain adalah bahwa REDUCE sejak awalnya memang diciptakan untuk digunakan dalam fisika sehingga gaya bahasanya dirasakan lebih cocok untuk para fisikawan.
\end{abstract}

Kata Kunci : silogisme, validasi, bahasa pemrograman REDUCE.

\section{Abstract}

Syllogism is a form of argumentation in logic. This research is aimed to produce computer program in symbolic computation to determine the validity of syllogism and then be applied to physics. The language chosen is REDUCED based on several considerations, one of which is because REDUCE is an open source language. Another consideration is that REDUCE from the beginning was made to be used in physics such that the style of the language is favorable to physicists.

Keywords: syllogism; validation; REDUCE programming language.

\section{PENDAHULUAN}

Komputasi secara garis besar dapat dibagi menjadi dua kelompok besar, yaitu komputasi numerik dan komputasi non-numerik. Komputasi numerik adalah komputasi dengan keluaran bilangan riil. Penekanan pada bilangan riil sangat penting karena inilah yang menyebabkan kesalahan pembulatan dan kesalahan pemotongan. Kedua jenis kesalahan itu menyebabkan komputasi numerik menjadi tidak mudah.

Komputasi non-numerik adalah komputasi dengan keluaran bukan bilangan riil. Komputasi yang hanya melibatkan bilangan bulat harus dimasukkan dalam kategori ini. Kesulitan pada komputasi ini adalah kompleksitas algoritma yang kemudian berkaitan dengan durasi komputasi yang panjang dan memori komputer yang besar. Komputasi non-numerik meliputi bidang yang sangat luas.

Correspondence: arief_hermanto@ugm.ac.id

Departemen Fisika, FMIPA, Universitas Gadjah Mada, Yogyakarta, Indonesia

Full list of author information is available at the end of the article ${ }^{*}$ Equal contributor
Selain bilangan bulat, keluarannya yang lain bisa berupa simbol-simbol non-numerik (misalnya dalam bidang linguistik), atau ekspresi matematik (yang komputasinya terkenal dengan istilah komputasi simbolik) dan contoh lain adalah keluaran yang berupa diagram.

Sebuah contoh yang sangat jelas adalah ketika kita menggunakan misalnya bahasa Matlab untuk menghasilkan sebuah gambar grafik. Karena gambar grafik adalah termasuk diagram, maka komputasinya itu boleh disebut sebagai komputasi diagramatik. Diagram yang dihasilkan komputasi diagramatik bisa berupa diagram yang statik; bisa pula berupa diagram yang mengandung kesan gerakan (sering disebut sebagai animasi). Tentu saja diagram, baik yang statik maupun animasi menjadi sangat berguna dalam fisika, yaitu sebagai visualisasi dari hasil simulasi suatu gejala.

Dalam penelitian ini akan digunakan komputasi simbolik dalam artian umum yaitu simbol-simbol matematik, misalnya yang menyangkut teori himpunan karena komputasi simbolik ini akan 
digunakan untuk menentukan validitas silogisme yang merupakan cabang dari argumentasi logika.

\section{STUDI PUSTAKA}

Fisika adalah ilmu yang sangat mendasar sehingga berkaitan dengan hal-hal yang kadang tidak terpikirkan, misalnya adanya hubungan fisika dengan retorik [1]. Mekanika Kuantum berkaitan dengan logika sehingga sebagian orang mengusulkan adanya Logika Kuantum [2, 3, 4, 5].

Proposisi adalah pengertian yang terkandung dalam kalimat. Satu proposisi bisa dinyatakan dalam berbagai kalimat dari berbagai bahasa dengan arti yang sama (atau hampir sama). Karena mengandung arti yang jelas maka proposisi mempunyai nilai kebenaran atau dengan kata lain proposisi bisa benar atau salah.

Fisika bisa dipandang sebagai kumpulan proposisi tentang materi-energi dan interaksinya yang saling berkaitan [6]. Keterkaitan antara berbagai proposisi adalah lewat argumentasi.

Argumentasi adalah kumpulan beberapa proposisi di mana salah satu di antara proposisi-proposisi itu merupakan kesimpulan atau konklusi sedangkan proposisi-proposisi yang lain merupakan alasan atau premis [7]. Jika semua premisnya benar dan secara logika kita bisa menjamin konklusinya pasti benar maka argumentasi itu disebut valid.

Proposisi dalam ilmu pengetahuan (termasuk fisika) adalah merupakan hasil rantai argumentasi yang valid berdasarkan premis proposisi yang lain, maka proposisi dalam fisika dijamin benar jika proposisi awal dimulainya argumentasi benar. Proposisi awal yang merupakan sumber segala proposisi yang lain itu disebut postulat dan memang postulat dianggap benar karena kesimpulan berdasarkan postulat itu harus cocok dengan hasil eksperimen.

Silogisme adalah salah satu bentuk argumentasi yang sederhana karena hanya terdiri atas 3 proposisi. Jadi ada 2 proposisi premis dan 1 konklusi atau kesimpulan. Silogisme sudah sangat lama ditemukan $[8,9,10]$. Sudah ada cara baku untuk menentukan validitas silogisme, namun cara itu bersifat manual. Dalam penelitian ini akan disusun program komputer untuk membuat penentuan validitas silogisme menjadi otomatis.

Karena silogisme merupakan bentuk yang boleh dikatakan paling sederhana dari argumentasi, sedangkan argumentasi itulah yang mengikat berbagai proposisi dalam fisika maka jelaslah aplikasi silogisme dalam fisika yaitu untuk mengikat berbagai proposisi dalam fisika sehingga menjadi jalinan yang sangat erat.

\section{METODE PENELITIAN}

Penelitian ini bersifat teoretik-komputatif sehingga langkah awal adalah studi literatur. Kemudian penentuan validitas silogisme dengan cara manual diteliti untuk diketahui kaitannya dengan metode komputasi simbolik yang sesuai. Nampaknya komputasi simbolik yang menggunakan simbol-simbol teori himpunan akan digunakan karena salah satu cara manual yang populer adalah dengan Diagram Venn. Selanjutnya disusun algoritma pemrograman dan kemudian dilakukan implementasi ke program.

Bahasa pemrograman yang dipilih adalah REDUCE berdasarkan beberapa pertimbangan. Yang pertama REDUCE adalah bahasa yang open source sehingga bebas untuk digunakan dengan men-download dari internet. Yang kedua REDUCE diciptakan pada awalnya untuk menyelesaikan masalah fisika oleh fisikawan. Ini mungkin berpengaruh pada gaya bahasanya yang lebih nyaman untuk digunakan bagi fisikawan. Yang ketiga REDUCE tetap aktif digunakan secara luas dan ada tempat penampungan makalah-makalah yang menggunakan REDUCE.

Tahap yang cukup panjang adalah validasi program karena program harus dicoba untuk berbagai kasus dan harus konsisten perilakunya. Setelah dirasa meyakinkan maka kita dapatkan program yang kita inginkan.

Tahap akhir penelitian adalah mengaplikasikan program kepada persoalan fisika yang berkaitan dengan silogisme. Silogisme berkaitan dengan 3 kata kunci. Dalam Fisika ada 3 kata kunci yang berkaitan dengan teori yaitu : Fundamental, Non-Lokal dan Deterministik. Ada 2 Teori Fisika yang sama-sama fundamental yaitu Relativitas dan Kuantum, namun berlawanan dalam 2 kata kunci yang lain. Kita akan mencoba apakah silogisme bisa memberikan pencerahan dalam hal ini.

Kita susun silogisme dalam bentuk sebagai berikut.

1 Semua teori yang non-lokal harus bersifat probabilistik.

2 Ada teori fundamental yang bersifat lokal (yaitu Relativitas)

3 Jadi, ada teori fundamental yang bersifat probabilistik (yaitu Teori Kuantum).

Jika digunakan program yang sudah disusun terbukti bahwa silogisme di atas valid.

\section{HASIL PENELITIAN}

Telah berhasil disusun program komputer untuk menentukan validitas silogisme dengan bahasa simbolik REDUCE. Program yang berhasil disusun ternyata tidak terlalu panjang sehingga bahkan bisa disusun beberapa versi sesuai dengan metode penyelesaian yang dirancang. 
Salah satu versi dari program komputer itu adalah sebagai berikut (Gambar 1).

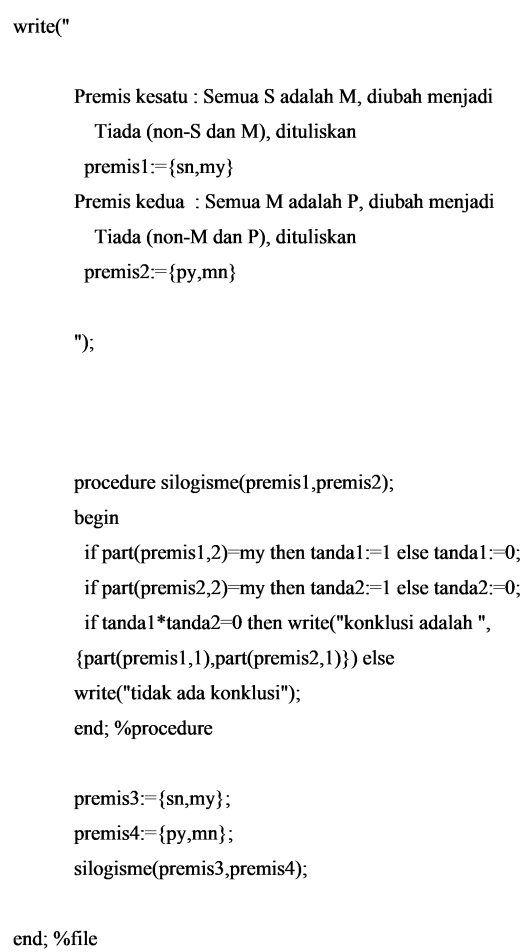

Gambar 1: Salah satu contoh source code program komputer.

\section{KESIMPULAN}

Penelitian ini telah berhasil menyusun beberapa program komputer dalam bahasa simbolik REDUCE untuk menentukan validitas silogisme. Langkah berikutnya adalah melihat apakah berbagai metode yang sudah berhasil dirancang untuk menyelesaikan masalah ini dapat mengerucut pada dihasilkannya suatu teorema matematik untuk menentukan validitas silogisme.

\section{PENULIS}

1 Arief Hermanto

Dari :

(1) Departemen Fisika, FMIPA, Universitas Gadjah Mada

\section{Pustaka}

1. Dykeman TB. The Physics of Rhetoric. College Composition and Communication. 1974;25(5):382-387.

2. Gibbins P. A user-friendly quantum logic. Logique et Analyse. 1985;28(112):353-362.

3. Hellman G. Quantum logic and meaning. In: PSA: Proceedings of the Biennial Meeting of the Philosophy of Science Association. vol. 1980. Philosophy of Science Association; 1980. p. 493-511.
4. Hughes RIG. Quantum logic. Scientific American. 1981;245(4):202-213.

5. Stachel J. The'logic' of 'quantum logic'. In: PSA: Proceedings of the Biennial Meeting of the Philosophy of Science Association. vol. 1974. D. Reidel Publishing; 1974. p. 515-526.

6. Rogers EM. Physics for the inquiring mind: the methods, nature, and philosophy of physical science. Princeton University Press; 1960.

7. Copi I. Symbolic Logic. New York: Macmillan Publishing Co., Inc; 1979.

8. Ganeri J. The Hindu syllogism: nineteenth-century perceptions of Indian logical thought. Philosophy East and West. 1996;p. 1-16.

9. Shorey P. The origin of the syllogism. Classical Philology. 1924;19(1):1-19.

10. Solmsen F. The discovery of the syllogism. The Philosophical Review. 1941;50(4):410-421. 